\title{
EFFECT OF MALTODEXTRIN RATIO TO KLUTUK BANANA FRUIT EXTRACT (MUSA BALBISIANA COLLA) COMBINED WITH ITS PSEUDOSTEM EXTRACT ON ANTI-DYSENTERY GRANULE PERFORMANCE AND EFFECTIVITY
}

\author{
SRI AGUNG FITRI KUSUMA ${ }^{*}$, SORAYA RATNAWULAN MITA², RATNA FITRIA ERMAWATI ${ }^{1}$
}

1Department of Biology Pharmacy, Faculty of Pharmacy, Padjadjaran University, Sumedang, West Java, Indonesia 45363, ${ }^{2}$ Departement of Pharmaceutics, Faculty of Pharmacy, Padjadjaran University, Sumedang, West Java, Indonesia 45363

Email: s.a.f.kusuma@unpad.ac.id

Received: 28 Aug 2018, Revised and Accepted: 12 Sep 2018

\section{ABSTRACT}

Objective: The objective of this study was to determine the best ratio of maltodextrin and extract concentration on performance of anti-dysentery granule containing Klutuk banana fruit extract (Musa balbisiana Colla) as an effective antimicrobial to treat dysentery caused by Shigella dysenteriae and combined with its pseudostem extract to supply potassium needed for supporting dehydration impact caused by dysentery.

Methods: The dried fruit and pseudostem of the Klutuk banana plant were each extracted by maceration method. Each granule formula was optimized in different ratio of extract and maltodextrin concentration (1:2 (F1); 1:3 (F2); and 1:4 (F3) respectively. Then, the anti-shigellosis granule were formulated using the wet granulation method and evaluated for $30 \mathrm{~d}$. The appearance of the granule, weight variation, loss on drying value, flowability, granule solubility, disintegration time, $\mathrm{pH}$, and anti-dysentery activity of each formula was observed. The potassium content determination of each granule formula was done using an atomic absorption spectrophotometer method.

Results: All formulated granules showed good flow properties and antidysentery activity. Concerning to the solubility, maltodextrin addition showed the increasing solubility of all formulated granule. The F3 achieved the best-improved granule characteristic and had good anti-dysentery effectivity, but had the lowest potassium content $(0.362 \mathrm{~g} / \mathrm{l})$ among all formulas. The potassium content of F1 and F2 were $0.625 \mathrm{~g} / \mathrm{l}$ and $0.444 \mathrm{~g} / \mathrm{l}$, respectively.

Conclusion: Maltodextrin can improve the usefulness of granule that containing the Klutuk banana fruit and its pseudostem extracts in dysentery treatment and the dehydration impact.

Keywords: Musa balbisiana Colla, fruit, extract, granule, maltodextrin, anti-dysentery

(C) 2018 The Authors. Published by Innovare Academic Sciences Pvt Ltd. This is an open-access article under the CC BY license (http://creativecommons.org/licenses/by/4.0/) DOI: http://dx.doi.org/10.22159/ijap.2018v10i6.29305

\section{INTRODUCTION}

Dysentery is a common gastrointestinal disorder primarily caused by Shigella dysenteriae but can potentially associate several systemic complications. S. dysenteriae is easily spread and found in an overcrowding population with malnutrition condition and poor of waste management and healthy water supplies [1]. The characterization of bacillary dysentery is diarrhea mixed with mucus and blood, accompanied by fever, tenesmus and abdominal cramps [2]. In children at age under 5 y old, for about $10 \%$ of all diarrhea cases are dysentery, and is reported to cause a higher mortality rate of $15 \%$ [3]. This data is synchronized with bacillary dysentery cases in Indonesia that $29 \%$ of deaths caused by dysentery occurred at age 1-4 y old [4]. The most causes of mortality that resulting from dysentery is dehydration. Because of diarrhea in high frequency, patients develop potassium depletion, called hypokalemia. The hypokalemia was signed with general muscular weakness, paralytic ileus and cardiac arrhythmias [5].

The dysentery must be treated by clinical improvement, avoiding the causative agent to limit pathogen transmission, preventing dehydration by administering appropriate fluids and food [3]. In addition, WHO also recommend antimicrobials such as amoxicillin, trimethoprim-sulfamethoxazole (TMP/SMX) for treating dysentery [6]. But it is very important to detect the sensitivity of Shigella clinical isolates because antimicrobial resistance was reported. A number of antimicrobials such as ceftriaxone (fluoroquinolones group) and azithromycin were considered to treat resistant shigella [7]. Newer fluoroquinolones, such as norfloxacin and ciprofloxacin are also effective for bacillary dysentery, but the price is very expensive. Beside that, the resistance of $S$. dysentery type 1 to quinolone antibiotics has been reported $[8,9]$. Therefore, a need of a new antibiotic candidate that effective and cheaper in prices leads scientists to explore new antimicrobial substances from medicinal plants $[10,11]$. The WHO has constituted a program to control diarrheal disease include the use of traditional medicines that combined with health education improvement and prevention method $[12,13]$.

Utilization of natural materials has been proven to be used as a natural antibiotic, especially for bacillary dysentery treatment. In Indonesia, bananas are an abundant agricultural commodity. Empirically, banana fruits have been used in the dysentery treatment and diarrhea disease $[14,15]$. Our previous research showed that fruit of Klutuk banana possessed a potential antimicrobial activity against $S$. dysenteriaea. The ethanolic extract of banana fruits contains flavonoid and tannin compounds that proved as the antibacterial agent against $S$. dysentriae. In addition, the pseudostem part of Klutuk banana also has a weak antimicrobial activity but has potassium content that is higher than the fruit. Therefore, in this study, the extracts of fruits and pseudostem combined to be formulated into anti-dysentery preparations that are also able to prevent hypokalemia.

Development of drugs containing plant extracts involves stability problems and technological because of the certain characteristics of extract that causing difficulties during pharmaceutical processing [16]. The active substances in extract often at low concentration as well as the rendemen. Whereas to produce an effective preparation, it required extract in large quantities to achieve an effective dose $[17,18]$. Therefore, the granulation technique was needed to improve dosage uniformity by inhibiting particle segregation [19, 20]. Granules are one of the drug form that more convenient in application than powder drug. The granules can swallow easily and they do not atomize nor adhere to the mucous membranes of the throat or the oral cavity [21]. The other advantages of granule preparation are chemically stable compared to the liquid form, convenient and suitable for large dosage preparations, and the rate of disintegration can be faster than that of tablets or capsules in oral administration [22]. The granules can also be given to pediatric patients who are still unable to swallow capsules or tablets properly. Generally, the use of granules may be administered to children by 
dissolving granules in water or by mixing them into semi-solid food [23]. However, the problem is that both of these test extracts are difficult to dissolve in water. For that, it is a necessary addition of excipients that can increase the solubility of the extract to develop improved granule with effective anti-dysentery activity. Maltodextrin is an adjuvant which is known to increase the solubility of the preparation and the active substance due to it is more likely hydrophilic in nature, thereby enhancing the water solubility of extract. Therefore, in this study, maltodextrin was added in the granular formulation that containing dissoluble extract to enhance the extraction solubility, so that anti-dysentery granule containing Klutuk banana fruits and its pseudostem ethanolic extract can be developed well and work effectively.

\section{MATERIALS AND METHODS}

\section{Materials}

The unripe fresh fruits and pseudostem of Klutuk banana (Musa balbisiana Colla) were collected from Cimincrang village, Gede Bage district, West Java, Indonesia. The identification of the plant was confirmed at the Institute of plant determination in the Department of Biology, Faculty of mathematics and natural sciences, Padjadjaran University, Jatinangor, Indonesia. The specimen number of the klutuk banana plant was HB/04/2016. The tested bacteria used in this study was Shigella dysenteriae ATCC 13313, obtained from the Laboratory of Microbiology, Faculty of Medicine, University Maranatha Kristen, Bandung, Indonesia. The growth medium used were ShigellaSalmonella agar (SS-Pronadisa), Mueller Hinton Agar (MHA-OXOID) and Mueller Hinton Broth (MHB-OXOID). The chemicals used were ethanol, $10 \%$ ammonia, amyl alcohol, $2 \mathrm{~N}$ hydrochloric acid, iron (III) chloride, ether, chloroform, anhydrous acetic acid solution in concentrated H2SO4, 1\% gelatin, reagent Dragendorff (potassium bismuth iodide solution). Mayer reagents (potassium mercury iodide solution), $10 \%$ vanillin solution in concentrated $\mathrm{H} 2 \mathrm{SO} 4,1 \mathrm{~N}$ sodium hydroxide, potassium permanganate powder, magnesium powder, and sterile physiological sodium chloride, maltodextrine, demineralized water, PVP, stevia sugar, aerosil and chocolate flavor.

\section{Extraction}

The fruits and banana pseudostem were washed with tap water chopped and dried. Then each $(500 \mathrm{~g})$ of dried material was ground into a fine powder and soaked in bottle maceration with $3 \mathrm{~L}$ of $70 \%$ ethanol. Solvent replacement was done for 3 times every $24 \mathrm{~h}$ in the same amount of solvent. All these maceration results were then concentrated using a rotary evaporator until viscous extracts of each material were obtained. Each extraction yield was calculated by dividing the viscous extract weight obtained by the of the dried material weight. The moisture content determination of each extract was analyzed using the distillation of toluene. The $2 \mathrm{~g}$ of thick extract was put into a clean and dry flask, then a volume of $200 \mathrm{ml}$ toluene was added. The flask was heated for $14 \mathrm{~m}$ carefully. After all the water had been distilled, the tube was allowed to cool at room temperature, then the volume of water was observed.

\section{Phytochemical screening}

The purposed of preliminary phytochemical analysis was to identify the secondary metabolites that present in fruit and pseudostem of Klutuk banana ethanolic extract. The phytochemical screening of alkaloids, flavonoids, polyphenols, tannins, monoterpenoids, sesquiterpenoids, steroids, triterpenoids, quinones, and saponins was carried out by following standard method [24].

\section{Granule formulation}

Based on our previous study, the best combination of both extracts as antidysentery and for hypokalemia prevention was $60 \% \mathrm{w} / \mathrm{v}$ : 7 $\% \mathrm{w} / \mathrm{v}$ for fruit and pseudostem extract, respectively. In this study, all granule formulations with different maltodextrin ratio were made. The total weight of each formula was $5 \mathrm{~g}$. In this granule formula, some of the excipient components were used, as follows: stevia sweetener, polyvinylpyrrolidone (PVP) was used as a binding agent, aerosil as adsorbent and disintegrant, maltodextrin was used to increase granule solubility, chocolate flavor was used for coloring granules, and $95 \%$ ethanol was used as granulation solvent. The detail of extract granule formulas could be seen in table 1 .

Table 1: Formulation of granule

\begin{tabular}{llll}
\hline Composition (\%w/w) & Formula 1 & Formula 2 & Formula 3 \\
\hline Fruit extract & 60 & 60 & 60 \\
Pseudostem extract & 7 & 7 & 7 \\
Sweetener (Stevia) & 5 & 5 & 5 \\
PVP & 1 & 1 & 1 \\
Aerosil & 1 & 1 & 1 \\
Maltodextrin & $1: 2$ & $1: 3$ & $1: 4$ \\
Chocolate Flavor & qs & qs & qs \\
$95 \%$ Ethanol & qs & qs & qs \\
\hline
\end{tabular}

The Klutuk banana ethanolic extracts of fruit and pseudostem were dried using aerosil and maltodextrin. Then stevia, chocolate flavor, and PVP were added to the extraction mixture. The mixture was stirred until homogeneous, crushed and sprayed with $95 \%$ ethanol gradually to form a mass that can be clinched. The mass was then sieved using mesh no. 10 to form granules, then the granules were dried in an oven at $40-50{ }^{\circ} \mathrm{C}$ for $18 \mathrm{~h}$. The dried granules were sieved again using a sieve no.16. The final granules formed were stored in a desiccator containing silica gel to avoid air humidity.

\section{Granule physical examination}

Physical appearance of granule was observed at room temperature $\left(27^{\circ} \mathrm{C}\right)$ at $75 \% \mathrm{RH}$ for a month, with interval observation every $3 \mathrm{~d}$ [25].

\section{Loss on drying test}

$2 \mathrm{~g}$ of granules was inserted in the moisture balance tool; then the moistures value was measured at $105^{\circ} \mathrm{C}$ until constant weight was achieved. The percentage value of loss on drying can be seen on the screen [26].

\begin{abstract}
Flowability test
The angle of repose and the Hausner ratio are conventionally used to characterize granule flow. The flowability test and angle of repose of the granule were conducted using flow tester equipped in the funnel with the nozzle. The angle of repose of the granules was evaluated by introducing a granule of $20 \mathrm{~g}$ into the flow tester, then the bottom of the funnel was opened so that the granules can flow. The time required by all the granules to pass through a funnel was calculated using a stopwatch. The flow rate is expressed as the number of $g$ of granules passing through the funnel per second. The angle of repose can be calculated by measuring the average diameter and peak height.
\end{abstract}

\section{Granule compressibility}

The compressibility of granules was determined using a bulk density tester. A weight of $20 \mathrm{~g}$ granule was poured slowly into a measuring cup and recorded as Vo. Then the granule in the measuring cup was tapped, and the volume change was recorded as Vt. The bulk density is calculated by dividing the granule weight by volume $\left(\mathrm{V}_{0}\right)$. Meanwhile, the tapped density is calculated by dividing the granule weight by volume (Vt). After that, the granule compressibility was 
calculated by the Carr index method and the Hausner ratio of how to divide the granule weight by volume.

\section{Granule solubility}

The solubility test of the granule is determined according to the solubility term which can be seen in table 2 .

\section{Granule disintegration time}

A weight of $8 \mathrm{~g}$ granules was dissolved in $200 \mathrm{ml}$ of distilled water. The test was performed using a magnetic stirrer at a temperature of $50{ }^{\circ} \mathrm{C}$ with a speed of $120 \mathrm{rpm}$. Then, the granules were inserted and the granule-dissolving time was calculated using a stopwatch. The best preference time required to dissolve granules was less than $5 \mathrm{~min}$ [28].

Table 2: Solubility of substance in a solvent [27]

\begin{tabular}{ll}
\hline Term solubility & The amount of solvent part is required to dissolve one part of the material \\
\hline Highly soluble & $<1$ \\
Easily Soluble & $1-10$ \\
Soluble & $10-30$ \\
Nearly difficult to dissolve & $30-100$ \\
Difficult to dissolve & $100-1000$ \\
Very difficult to dissolve & $1000-10000$ \\
Practically insoluble & $>10000$ \\
\hline
\end{tabular}

\section{pH solution}

Granule weighed as much as $5 \mathrm{~g}$ then dissolved in $100 \mathrm{ml}$ distilled water. Then a $\mathrm{pH}$ measuring device that has been calibrated using buffer $\mathrm{pH} 4$ and $\mathrm{pH} 7$ was fed into the granule solution, and the measured $\mathrm{pH}$ was recorded.

\section{Preparation of Mc Farland solution}

Preparation of Mc Farland's standard solution was done by mixing $0.05 \mathrm{ml}$ of $1,175 \% \mathrm{BaCl}_{2}$ solution with $9.95 \mathrm{ml}$ of $1 \% \mathrm{H}_{2} \mathrm{SO}_{4}$ solution then it was shaken until homogeneous. Turbidity of the solution was measured at a wavelength of $625 \mathrm{~nm}$ using distilled water as a blank. The absorbance value of the solution should be in the range of 0.08 to 0.13 . The standard McFarland 0.5 solutions are equivalent to a bacterial cell suspension that having a concentration of $1 \mathrm{x}$ $10^{8} \mathrm{CFU} / \mathrm{ml}[29]$.

\section{Antibacterial effectiveness test}

The anti-dysentery effectivity test of the granules was assayed using the agar diffusion method with perforation technique. Granules from each formula were dissolved in sterile aquadest and diluted to achieve tested concentration, i.e. 30,40 and $50 \% \mathrm{w} / \mathrm{v}$. A total of $20 \mu \mathrm{l}$ bacterial suspension was poured into sterile Petri dishes and suspended in $20 \mathrm{ml}$ of the MHA, then homogenized. The medium was allowed to solidify to be perforated to prepare the holes for storing the extract. Each granule solution with a different concentration of $100 \mu \mathrm{L}$ was fed into the hole. The negative and positive control was prepared, where the negative control contains only medium, meanwhile the positive control consisted of the inoculated bacterial suspension using the streak inoculation method. All test and control media were incubated at $37^{\circ} \mathrm{C}$ for $24 \mathrm{~h}$. The inhibitory diameter formed was measured using a caliper [30].

\section{Potassium level measurement}

Samples were prepared by dry destruction methods and analyzed using Atomic Absorption Spectrophotometry (SSA). As much as $1 \mathrm{~g}$ granule of each formula, weighed and heated at a temperature of $600{ }^{\circ} \mathrm{C}$ to form ash. A total of $10 \mathrm{ml}$ of $6.5 \% \mathrm{HNO}_{3}$ was reacted to ash and reheated on a hot plate. The mixture was filtered and fed into a $25 \mathrm{ml}$ flask, then demineralized water was added to the boundary marker. The test sample solution was ready to be measured. Before use, a $1 \mathrm{~g}$ of solid $\mathrm{KCl}$ was dried for $2 \mathrm{~h}$ at $100^{\circ} \mathrm{C}$ and then cooled for $30 \mathrm{~min}$. To prepare a standard potassium solution, $\mathrm{KCl}$ was weighed $25 \mathrm{mg}$ and fed into a $25 \mathrm{ml}$ measuring flask to obtain a standard potassium solution at $1000 \mu \mathrm{g} / \mathrm{ml}$. Furthermore, demineralized water was added to the measurement marks, and shaken until all homogeneous solutions, to obtain a stock solution of $1000 \mathrm{ppm}$. The standard solution of potassium was diluted in various concentrations with the addition of demineralized water. The absorbance of the standard solution resulting from dilution was measured using atomic absorption spectroscopy. The blank used for measurement was demineralized water. The measurement was carried out by inserting a hose into the standard solution with the smallest concentration to the highest concentration. The absorbance measurement results were recorded and calculated linear regression so that a straight line equation was obtained to see the linearity [31].

\section{RESULTS AND DISCUSSION}

\section{Extraction results}

The thick extract obtained from the extraction process of $500 \mathrm{~g}$ of fruit and pseudostem Klutuk banana was $35.85 \mathrm{~g}$ and $16.54 \mathrm{~g}$, respectively. Both extracts displayed the same morphological appearance of dark brown, distinctive odor, and bitter taste. The water content of both extracts was $5 \%$. This value is in accordance with the requirements given for water content that is less than $10 \%$. The less moisture content of the extract, the less likely the occurrence of extract contamination by microorganisms.

\section{Phytochemical screening of extracts}

Based on phytochemical screening results, it was found that ethanol extract of fruit and psedostem of klutuk banana contained the same compounds, as follows: flavonoids, polyphenols, tannins, monoterpenoids and sesquiterpenoids, quinones, and saponins. As our previous study, mentioned that the fruit ethanolic extract of klutuk banana had potent anti-dysentery activity against $S$. dysenteriae. In another study, the same secondary metabolite content in the extract of Tabernaemontana divaricate provides antidysentery activity [32]. These data showed that those metabolites responsible for the anti-dysentery activity against $S$. dysenteriae. The function of flavonoids worked by forming complex compounds against bacterial extracellular proteins that interfere with the integrity of bacterial cell membranes. Flavonoids may also interact with bacterial DNA so that it caused damage to the cell wall permeability of bacteria, microsomes, and lysosomes. Meanwhile, the polyphenols can coagulate bacterial protein and made lysis of bacterial cell membrane [33]. In addition, a research study informed that the banana fruit extract content higher total phenolic compounds than its peel [34]. The presence of saponins in the extract content also increasing the permeability and reduce the surface tension of cell walls through the interaction of saponins with lipopolysaccharide in the bacterial cell wall. This caused the cell wall lysis and disrupted the cell's metabolism [35, 36]. As an antibacterial, tannins can damage cell membranes and shrank cell walls, thus damaging bacterial cell permeability which eventually leads to bacterial death [37].

\section{Solubility test result of the component formula}

In drug invention, almost $70 \%$ of new drug candidates found as an insoluble drug due to perform poor water solubility [38]. These poor solubility reflects the drug dissolution in gastrointestinal fluids that can limit the in vivo bioavailability, especially for oral administration. Therefore, the solubility of active substances and excipients is very important in determining the solubility of a drug preparation. In this study, before formulation, all the components of 
the formula were tested for their solubility in water. A component of the formula was considered as a soluble component if the amount of solvent part that is required to dissolve one part of the material is not more than 30 parts. Otherwise, the substance is considered poorly soluble. Based on the results of the solubility test, it is known that both extracts were difficult to dissolve in water, while other excipient ingredients were easily soluble in water. Therefore, to attempt its effectiveness, both extracts must be formulated using excipient ingredients that can increase their solubility by the addition of maltodextrin.

\section{Formulation and evaluation of anti-dysentery granule}

The use of complexing carbohydrates agents with water was one of the recent strategies conducted to improve drug solubility by forming a water-soluble inclusion complex of the drug [39]. The complexation was purposed to stabilize the drug chemically and modified the lipid barrier to enhance the absorption of the drug [40]. Because of this complexation process, poorly soluble extract of Klutuk banana could be effectively delivered to the desired target. These supramolecular systems using carbohydrate will be developed consistently in the field of pharmaceutical and medical application. The mechanism of each carbohydrate type are varied [41]. In this study, the type of carbohydrate used as a diluent was polysaccharide namely maltodextrin. Maltodextrin is a kind of polysaccharide as a hydrolysis product of starch. In addition to its solubility effect, maltodextrin can be used in food because it has advantageous characteristics such as: fast dispersion, tasteless without having its own pharmacological activity and crystallization inhibitor. In this study, three granule formulas were obtained with variations in the concentration ratio of extract compared to maltodextrin. Maltodextrin in this formula was made to vary in order to increase the solubility of extracts in granules and accelerate the drying process of extracts [42, 43]. The color of this antidysentery granules was dark-brown with a characteristic odor. This anti-dysenteri granule can be applicated for all ages, especially for people who cannot swallow drugs and children.

\section{Physical evaluation of granules}

The physical appearance of granules was observed at room temperature $\left(27^{\circ} \mathrm{C}\right)$. The initial average weight of the granule corresponds to the total composition weight formulated. But during its storage time, the weight of the granules has increased. These can be assumed due to the moisture content increased of the granules. However, there was no physical change in the all granules of the formula. The granule observation results can be seen in table 2 .

Table 2: The average of granules weight during storage time

\begin{tabular}{llll}
\hline Time of observation (day) & Granule weight (g) & F2 & F3 \\
\cline { 2 - 4 } & F1 & $5.000 \pm 0.0000$ & $5.000 \pm 0.0000$ \\
& $5.000 \pm 0.0000$ & $5.081 \pm 0.0004$ & $5.082 \pm 0.0000$ \\
3 & $5.083 \pm 0.0004$ & $5.087 \pm 0.0004$ & $5.089 \pm 0.0004$ \\
6 & $5.091 \pm 0.0004$ & $5.121 \pm 0.0000$ & $5.122 \pm 0.0000$ \\
9 & $5.124 \pm 0.0000$ & $5.128 \pm 0.0004$ & $5.129 \pm 0.0004$ \\
12 & $5.133 \pm 0.0004$ & $5.148 \pm 0.0004$ & $5.149 \pm 0.0004$ \\
15 & $5.151 \pm 0.0004$ & $5.167 \pm 0.0004$ & $5.168 \pm 0.0004$ \\
18 & $5.174 \pm 0.0004$ & $5.174 \pm 0.0000$ & $5.176 \pm 0.0000$ \\
21 & $5.182 \pm 0.0004$ & $5.183 \pm 0.0004$ & $5.185 \pm 0.0004$ \\
24 & $5.191 \pm 0.0004$ & $5.196 \pm 0.0004$ & $5.189 \pm 0.0004$ \\
30 & $5.233 \pm 0.0004$ & $5.210 \pm 0.0004$ & $5.240 \pm 0.0004$ \\
\hline
\end{tabular}

\section{Loss on drying result}

From the results, it was known that the loss on drying granules of formula 1,2 and 3, respectively 3.9; 2.5 ; and $4 \%$. These data can be correlated with granular moisture, which causes granular weight changes for $30 \mathrm{~d}$ of storage. However, the percentages of loss on drying were in the normal range of requirement at range between 2$4 \%$ [44]. Percent LOD values of granule formula which comply with the requirement limits indicated the formulation content lower moisture value.

\section{Flowability test results}

All granules had excellent flow rates for all formulas, which were 19.49; 20.07 and 20.39 , in accordance with the relationship between flowability and flow character which was very good, for about $>10$. The angle of repose measurement was aimed to determine the characteristics of the fluidity associated with the cohesiveness between the constituent particles. The angle of repose would increase if the particle size becomes smaller [45]. The angle of repose value was 25.70 (formula 1); 25.25 (formula 2) and 24.53 (formula 3). This is consistent with the results of the formula 3 flowability which was $<25 \mathrm{~g} / \mathrm{sec}$ thereby determining the excellent flow character of the granule. Formula 3 had good flow characteristics based on the value of repose angle and granular flowability. Therefore, it can be concluded that the higher the maltodextrin level, the better the granular flow character.

\section{Compressibility index}

The Compressibility index (Carr's index) is a propensity measurement of a powder to be compressed that is determined from the tapped and bulk densities. The values of the granule bulk density were 0.65 (F1), 0.57 (F2) and 0.67 (F3), while the tapped density values were 0.77 (F1), 0.71 (F2) and 0.71 (F3). Based on the results of bulk and tapped density, the granule flow character can be calculated using the Index Carr and Hausner ratio formula. Based on the Carr Index calculation, it was known that formula 3 (F3) had the lowest Carr Index value of $5.63 \%$ among all formulas. This value showed that the F3 was the most flowable granule because the less compressible a material, the more it is flowable. However, the other formulas were in a range of good flow characteristics with its Carr index value of $15.58 \%$ for $\mathrm{F} 1$ and $19.72 \%$ for $\mathrm{F} 2$. If the there is a greater difference value between tapped and bulk density, so there will be a greater inter-particle interaction and can be categorized as poor flowing granule. While the results of the Hausner ratio calculation were as follows: 1.18 (F1), 1.25 (F2) and 1.06 (F3). Thus, it can be concluded that F3 with the highest maltodextrin content produced excellent granule flow.

\section{Granule solubility results}

Formulate the poorly soluble extract and improving their bioavailability is an important effort in pharmaceutical science. Thus, the in data of in vitro dissolution has been an important step to be analyzed in drug development $[46,47]$. In this study, the amount of water as a solvent needed to dissolve 1 part granule for formula 1 was $30 \mathrm{ml}$ while of formula 2 was $25 \mathrm{ml}$ and formula 3 was $20 \mathrm{ml}$. Thus, all granule formulas were performed as water-soluble preparations. This data showed that there was a significant effect by adding maltodextrin to the granule formula. Considering that both extracts as the active component were difficult to dissolve in water. The extract dissolution with a high aqueous solubility was very important to the therapeutic effect, especially for oral administration. Because this solubility parameter was one of the fundamental parameters for it's in vivo bioavailability that control the rate and extract absorption $[48,49]$.

\section{Granule dissolution time results}

The dissolution time is a very important to determine the rate of the granule to pass into the solution [50]. As expected, the granule 
release was dependent on the concentration of maltodextrin in all formulations. The measurement results show that formula 3 has a faster soluble time of $3.26 \mathrm{~min}$ compared to formula F1 (4.10 min) and F2 (3.5 $\mathrm{min}$ ). In theory, the best time required for the granule to dissolve is less than 5 min [28]

\section{pH granule solution}

One of the critical effect after oral drug administration is a pH risk of injury on the stomach, esophagus, and duodenum. In addition, the acid or base character of the drugs was an important key that affects their biopharmaceutical properties. Therefore the $\mathrm{pH}$ of the pharmaceutical form must be evaluated. $\mathrm{pH}$ testings were carried out on the base granule solution, all formula granules, ethanol extract solution, fruit and its pseodostem of Klutuk banana. The results showed that the $\mathrm{pH}$ of the three granule formulas ( $\mathrm{F} 1=5.65$; $\mathrm{F} 2=5.67 ; \mathrm{F} 3=6.20)$, the $\mathrm{pH}$ of fruit banana ethanol extract $(5.86)$ and the $\mathrm{pH}$ of pseudostem (5.89) was acidic, whereas the granule base had a relatively neutral $\mathrm{pH}$ of 7.03 . Based on these $\mathrm{pH}$ evaluations, the higher maltodextrin concentration in formula could increase the $\mathrm{pH}$ of the extract to a $\mathrm{pH}$ corresponding to the normal range $\mathrm{pH}$ of the colon. However, the better $\mathrm{pH}$ for the base target was the base $\mathrm{pH}$. Because the $\mathrm{pH}$ of the solid drug, have better solubility closely at range $\mathrm{pH} 7.0$ for resulting in colon targeted system. The formula 3 with a highest maltodextrine concentration was hypothesized as the best formula with the increasing $\mathrm{pH}$ ability.

\section{Antibacterial effectiveness result}

The antibacterial activity of all granules formulas against $S$ dysenteriae examined in the present study was qualitatively assessed by the presence of inhibition zone and zone diameter measurement, as given in the tables 3 .

Table 3: Antibacterial effect of all granule formulas

\begin{tabular}{lll}
\hline Formula & Concentration $(\% \mathbf{w} / \mathbf{v})$ & Inhibition zone diameter (mm) \\
\hline Formula 1 & 30 & $15.50 \pm 0.0001$ \\
& 40 & $16.53 \pm 0.0001$ \\
Formula 2 & 50 & $16.86 \pm 0.0001$ \\
& 30 & $15.30 \pm 0.0004$ \\
Formula 3 & 40 & $16.40 \pm 0.0002$ \\
& 50 & $16.65 \pm 0.0004$ \\
& 30 & $15.20 \pm 0.0004$ \\
& 40 & $15.73 \pm 0.0004$ \\
\hline
\end{tabular}

Note: perforator diameter: $8.8 \mathrm{~mm}$

Among all the formula, formula 1 performed the highest anti-dysentery activity due to the lower concentration of maltodextrin in the formula, gave the higher extract portion of concentration in the ratio of extract and maltodextrine. In formula 1 content the biggest concentration of fruit extract that had been studied as the potent anti-dysentery herb candidate. As it is shown in table 3 , the greater concentration of klutuk banana ethanol extract produced the bigger diameter of the inhibitory zone. Based on the inhibitory zones diameter, all tested formula could be categorized as a very active antibacterial, because they resulted in the diameter of inhibition above $11 \mathrm{~mm}$ [51]

\section{Statistical analysis results}

Statistical analysis was carried out to determine the effect of differences in formulas and differences in concentration as well as the possibility of interactions occurring so as to affect the diameter of the inhibition. The statistical method used was ANAVA Factorial Design in order to study the interaction between the difference in formula and an increase in concentration. Sometimes the two factors are mutually synergistic to the (positive) response. But sometimes the existence of a factor actually inhibits the performance of other factors (negative). The existence of these two mechanisms tends to increase the influence of interaction between the two factors. ANAVA test results can be seen in table 4 .

Based on the factorial design results presented in table 4, there was an influence between the variations of the formula to the inhibition zone diameter. There was an effect between increasing the concentration of the inhibition zone diameter and influence between the variation of the formula and increasing the concentration of the inhibition zone diameter. This could be seen from the sig value. = 0.00 which has a smaller value than the real level $(\alpha=0,05)$. Because Ho was rejected, it was necessary to do the further tests using the Tukey test to determine the differences in the effects of formula 1, 2 and 3 on the inhibitory diameter and the different effects of each concentration on ian nhibitory diameter that could be seen in table 5 .

Table 4: ANAVA test results of the formula and concentration difference effect

\begin{tabular}{lllll}
\hline Source & Type III sum of squares & Df & Mean square & Sig. \\
\hline Corrected Model & $20.496^{\mathrm{a}}$ & 8 & 2.562 & 0.00 \\
Intercept & 4549.626 & 1 & 4549.626 & 0.00 \\
Formula & 7.038 & 2 & 3.519 & 2720706.68 \\
Konsentrasi & 12.027 & 2 & 6.014 & 2104.395 \\
F*K & 1.431 & 4 & 0.358 & 3596.183 \\
Error & 0.015 & 9 & 0.002 & 213.897 \\
Total & 4570.137 & 18 & & 0.00 \\
Corrected Total & 20.511 & 17 & & 0.00 \\
\hline
\end{tabular}

Table 5: Tukey test result

\begin{tabular}{|c|c|c|c|c|c|c|c|}
\hline \multirow[t]{2}{*}{ (I) Formula } & & & \multirow[t]{2}{*}{ Mean difference (I-J) } & \multirow[t]{2}{*}{ Std. Error } & \multirow[t]{2}{*}{ Sig. } & \multicolumn{2}{|c|}{ 95\% confidence interval } \\
\hline & & & & & & Lower bound & Upper bound \\
\hline \multirow[t]{6}{*}{ Tukey HSD } & 1 & 2 & $-.1183^{*}$ & .02361 & .002 & -.1843 & -.0524 \\
\hline & & 3 & $1.2633^{*}$ & .02361 & .000 & 1.1974 & 1.3293 \\
\hline & 2 & 1 & $0.1183^{*}$ & .02361 & .002 & .0524 & .1843 \\
\hline & & 3 & $1.3817^{*}$ & .02361 & .000 & 1.3157 & 1.4476 \\
\hline & 3 & 1 & $-1.2633^{*}$ & .02361 & .000 & -1.3293 & -1.1974 \\
\hline & & 2 & $-1.3817^{*}$ & .02361 & .000 & -1.4476 & -1.3157 \\
\hline
\end{tabular}


Based on the results of the Tukey test, it could be seen that there were significant differences between each formula of the inhibition zone diameter. The value of $\mathrm{p}$-value $=0.002<=0.05$ then $\mathrm{H} 01$ was rejected, meaning that there were differences in Formula 1 and 2 to the diameter of the inhibitory zone. The value of p-value $=0,000<=0,05$ then $\mathrm{H} 02$ was rejected, mean that there were differences in Formula 1 and 3 to the diameter of the inhibitory zone. The value of $p$-value $=$ $0,000<=0,05$ then $\mathrm{H} 03$ rejected mean that there were differences in Formula 2 and 3 to the diameter of the inhibitory zone.

\section{Potassium quantitative analysis}

Based on the results of the potassium concentration analysis, formula 1 had a potassium content of $0.625 \mathrm{~g} / \mathrm{l}$, while formula 2 had a potassium content of $0.444 \mathrm{~g} / \mathrm{l}$ and formula 3 had a potassium content of $0.362 \mathrm{~g} / \mathrm{l}$. The body needs potassium as much as $15-25$ $\mathrm{mEq}$ which is equivalent to $0.585-0.975 \mathrm{~g} / \mathrm{l}$ [7]. So that, all granule formulas comply a body potassium requirement and could be a natural anti-hypokalemia.

\section{CONCLUSION}

Anti-dysentery granules formulated from the ethanolic fruit and the pseudostem extract of Klutuk banana and optimized using different ratios of maltodextrin concentration were found to comply the standards of granule performance, had potent anti-dysentery activity and could be a strong anti-hypokalemia drug candidate.

\section{AUTHORS CONTRIBUTIONS}

All the authors have contributed equally

\section{CONFLICT OF INTERESTS}

Declared none

\section{REFERENCES}

1. Niyogi S. Shigellosis. J Microbiol 2005;43:133-43.

2. Bhattacharya SK, Sur D. An evaluation of current shigellosis treatment. Expert Opin Pharmacother 2003;4:1315-20.

3. Yu CE, Lougee DA, Murno JR. Diarrhea and dehydration. Pediatric Education in Disasters Manual. Service Point S. A, Buenos Aires; 2009. p. 189-94.

4. Nafianti S, Sinuhaji AB. Resisten trimetoprim-sulfametoksazol terhadap shigellosis. Sari Pediatri 2005;7:39-44.

5. World Health Organization Pathopysiology of Watery Diarrhoea: Dehydration and Rehydration. Geneva; 1992.

6. Lima AAM, Lima NL, Pinho MC. High frequency of strain multiply resistant to ampicillin, trimethoprim-sulfametoksazol, streptomycin, subject: chloramphenicol, and metracycline isolated from a patient with shigellosis in Northeastern Brazil during period 1988 to 1993. Antimicrob Agents Chemother 1995;9:256-79.

7. WHO. The treatment of diarrhoea: a manual for physicians and other senior health workers. Geneva; 2005.

8. Sivapalasingam S, Nelson JM, Joyce K, Hoekstra M, Angula FJ, Mintz ED. High prevalence of antimicrobial resistance among Shigella isolates in the United States tested by the National Antimicrobial Resistance Monitoring System from 1999 to 2002. Antimicrob Agents Chemother 2006;50:49-54.

9. Dutta S, Ghosh A, Ghosh K, Dutta D, Bhattacharya SK, Nair GB. Newly emerged multiple antibiotic-resistant Shigella dysenteriae type 1 strains in and around Kolkatta, India, are clonal. J Clin Microbiol 2003;41:5833-4.

10. Clark AM. Natural products as a resource for new drugs. Pharm Res 1996;13:1133-41.

11. Cordell GA. Biodiversity and drug discovery a symbiotic relationship. Phytochem 2000;55:463-80.

12. Goleniowski ME, Bongiovanni GA, Bongiovanni L, Palacio CO, Cantero JJ. Medicinal plants from the sierra de comechingones, argentina. J Ethnopharmacol 2006;107:324-41.

13. WHO. Report of the second meeting of Directors of WHO Collaborating centres for traditional medicine. Geneva. Swiazerland; 1987.

14. Ghani A. Medicinal plants of bangladesh: chemical constituents and uses: 2003. $2^{\text {nd }}$ ed. The Asiatic Society of Bangladesh, Dhaka; 2003. p. 315.

15. Khare CP. Indian medicinal plants. Springer Science+Bussiness Media, New York; 2007. p. 426.
16. Kusuma SAF, Soraya RM, Indah F, Resmi M. Study on the antibacterial activity of fruit extracts of Klutuk Banana (Musa balbisiana colla) against Shigella dysenteriae ATCC 13313. Asian J Pharm Clin Res 2017;10:220-3.

17. Souza TP de, Jose Luiz GA, Ramon MP, Pedro RP. Development of granules from Phyllanthus nirurispray-dried extract. Braz J Pharm Sci 2009:45. http://dx.doi.org/10.1590/S198482502009000400009 .

18. Crippa F. Problems of pharmaceutical technics with plant extracts. Fitoterapia 1978;49:257-63.

19. Bonati A. Problems relating to the preparation and use of extracts from medicinal plants. Fitoterapia 1980;1:5-12.

20. Soares LAL, George GO, Petrovick PR, Schmidt PC. Dry granulation and compression of spray-dried plant extracts. AAPS PharmSciTech 2005:6:E359-66.

21. Souza TP, Martinez PR, Gomez AJL, Petrovick PR. Eudragit E as an excipient for production of granules and tablets from phyllanthus niruri L spray-dried extract. AAPS PharmSciTech 2007;8:E1-E7.

22. Bauer KH, Fromming KH, Führer C. Pharmazeutische technologie, mit einführung in die biopharmazie. $9^{\text {th }}$ ed. Wissenschaftliche Verlagsgesellschaft, Stuttgart; 2012.

23. Aulton ME. Pharmaceutics: the science of dosage forms design Churchill Living Stone, London; 2002.

24. Nales, Diana A van Riet, Alfred FAM Schobben, Herman Vromans, Toine CG Egberts, Carin MA. Safe and effective pharmacotherapy in infants and preschool children: the importance of formulation aspects. Br Med J 2015;101:1-8.

25. Farnsworth NR. Biological and phytochemical screening of plant. J Pharm Sci 1966;55:243-69.

26. Palanisamy $\mathrm{P}$, Abihishekh R, Kumar DY. Formulation and evaluation of instant tablets of acelofenac. Int J Res Pharm 2012;2:185-190.

27. Agoes G. Sediaan Farmasi Padat (SFI-6). Penerbit ITB Press, Bandung; 2012.

28. Depkes RI. Farmakope. $4^{\text {th }}$ ed. Depkes, Jakarta; 1995.

29. Siregar CJP. Teknologi farmasi sediaan tablet dasar-dasar praktis. Penerbit EGC, Bandung; 2007. p. 275-80.

30. Irith W, Hilpert K, Robert EWH. Agar broth and broth dilution methods to determine the minimal inhibitory concentration (MIC) of antimicrobial substances. Nat Prot 2008;3:163-5.

31. Kusuma SAF, Marlene A, Bobby EV. Formulation and evaluation of anti-acne gel containing citrus aurantifolia fruit juice using carbopol as a gelling agent. Int J Appl Pharm 2018;10:147-52.

32. Raimon. Perbandingan Metode Destruksi Basah dan Kering Secara Spektrofotometri Serapan Atom. Lokakarya Nasional Jaringan Kerjasama Kimia Analitik Indonesia. Yogyakarta; 1993.

33. Kumari S, Mazumder A, Bhattacharya S. Pharmacognostical and antimicrobial studies of the stem of Tabernaemontana divaricata Linn. Int J Pharm Pharm Sci 2015;7:101-4

34. Juliantina FF, Citra DW, Nirwani B, Nurmasitoh T, Bowo T. Manfaat sirih merah (piper crocatum) sebagai agen anti bakterial terhadap bakteri gram positif dan gram negatif. JKKI, Jakarta; 2009.

35. Ahmad B, Mohd KS, Abdurrazak M, Rao M, Zin T. Phytochemical screening, the antioxidant activity of pure syringing in comparison to various solvents extracts of Musa paradisiaca (Banana) (Fruit and Flower) and total phenolic contents. Int J Pharm Pharm Sci 2015;7:242-7.

36. Arabski MS, Wasik K, Dworecki W, Kaca. Laser interferometric and cultivation methods for measurement of colistin/ampicillin and saponin interaction with smooth and rough of Proteus mirabilis lipopolysaccharides and cells. J Microb Methods 2009;77:179-83.

37. Karlina CY, Ibrahim M, Trimulyono G. Aktivitas antibakteri ekstrak herbal krokot (Portulaca oleracea L.) terhadap Staphylococcus aureus dan Escherichia coli. J UNESA Lentera Bio 2013;2:87-93.

38. Ajizah A. Sensitivitas Salmonella typhimurium terhadap Ekstrak Daun Psidium guajava L. Bioscientiae 2004;1:31-8.

39. Kawabata Y, Wada K, Nakatani M. Formulation design for poorly water-soluble drugs based on biopharmaceutics classification system: basic approaches and practical applications. Int J Pharm 2011;420:1-10. 
40. Loftsson T, Brewster ME. Pharmaceutical applications of cyclodextrins. Drug solubilization and stabilization. J Pharm Sci 1996;85:1017-25.

41. Huiloh Z, Samanta AK, Heng PW. Overview of milling techniques for improving the solubility of poorly water-soluble drugs. Asian J Pharm Sci 2015;10:255-74.

42. Cho E, Jung S. Supramolecular complexation of carbohydrates for the bioavailability enhancement of poorly soluble drugs. Mol 2015;20:19620-46.

43. Chronakis, Ioannis S. On the molecular characteristics, compositional properties, and structural-functional mechanisms of maltodextrins: a review. Crit Rev Food Sci 2012;38:599-637.

44. Preis M, Miriam P, Breitkreutz J. Orodispersible film containing dimenhydrinate. Pharmaceutics 2012;4:551-62.

45. Lachman L, Lieberman HA, Kanig JL. Teori dan praktek farmasi industri. $2^{\text {nd }}$ ed. UI Press, Jakarta; 1994.
46. Parrot EL. Pharmaceutical technology fundamental pharmaceutics. Burgess Publishing Company, Mineapolis; 1971.

47. $\mathrm{Hu}$ J, Johnston KP, Williams RO. Nanoparticle engineering processes for enhancing the dissolution rates of poorly water soluble drugs. Drug Dev Ind Pharm 2004;30:233-45.

48. Costa P, Sousa JM. Lobo modeling and comparison of dissolution profiles. Eur J Pharm Sci 2001;13:123-33.

49. Prakash K, Jieun R, Hyeongmin K, Iksoo K, Jeong TK, Hyunil K, et al. Pharmaceutical particle technologies: an approach to improve drug solubility, dissolution and bioavailability. Asian J Pharm Sci 2014;9:304-16.

50. Amidon GL, Lennernas H, Shah VP. A theoretical basis for a biopharmaceutic drug classification: the correlation of in vitro drug product dissolution and in vivo bioavailability. Pharm Res 1995;12:413-20

51. Williams HD, Trevaskis NL, Charman SA. Strategies to address low drug solubility in discovery and development. Pharmacol Rev 2013;65:315-499. 